\title{
PENDAMPINGAN PROGRAM SEKOLAH SIAGA BENCANA BERBASISKAN MASYARAKAT PADA SEKOLAH BUDI AGUNG JAKARTA
}

\author{
Farid Fauzi ${ }^{1}$, Sri Rahayu Handayani ${ }^{2}$ \\ ${ }^{1}$ IAIN Takengon, Aceh Tengah, Indonesia \\ ${ }^{2}$ Sekolah Budi Agung, Jakarta Utara, Indonesia \\ email: faridfauzi1869@yahoo.com ${ }^{1,2}$
}

\begin{abstract}
Disaster preparedness is important for the life of every human being in dealing with disaster situations, whether caused by nature or humans. Schools are institutions engaged in public services in the field of education and teaching must provide a sense of security from the process of a disaster, so that in this case a community-based disaster preparedness school assistance program is needed, especially the school community and around schools located at Budi Agung Jakarta School with the PAR method (Participatory Action Research) through a cyclical process consisting of planning, action, evaluation and reflection. Participants in this assistance consist of educators, education staff and the community around the school, totaling 85 participants. Based on the evaluation results of the disaster preparedness school mentoring process, there was a significant increase in knowledge by $11 \%$, attitudes by $20.8 \%$, action by $14.4 \%$ and response by $15.8 \%$. based on the results of the assessment, the implementation of this assistance underwent one cycle. It can be concluded that the assistance of disaster preparedness schools at the Budi Agung Jakarta School is very effective in tackling disaster events or disaster preparedness that will occur.
\end{abstract}

Keywords: Disaster Prepared School, Local Communities

\begin{abstract}
Abstrak: Kesiapsiagaan bencana merupakan hal yang penting bagi kehidupan setiap manusia dalam menghadapi keadaan bencana, baik itu yang disebabkan oleh alam dan manusia. Sekolah merupakan institusi yang bergerak dibidang pelayanan publik dalam bidang pendidikan dan pengajaran harus memberikan rasa aman dari proses terjadinya bencana, sehingga dalam hal ini diperlukan program pendampingan sekolah siaga bencana berbasiskan masyarakat khususnya masyarakat sekolah dan disekitar sekolah yang berada pada Sekolah Budi Agung Jakarta dengan metode PAR (Participatory Action Research) melalui proses siklus yang terdiri dari perencanaan, aksi, evaluasi dan refleksi. Peserta pendampingan ini terdiri dari tenaga pendidik, tenaga kependidikan dan masyarakat disekitar sekolah yang berjumlah 85 perserta. Berdasarkan hasil evaluasi dari proses pendampingan sekolah siaga bencana terdapat peningkatan yang cukup siginifkan dari segi pengetahuan sebesar $11 \%$, sikap sebesar $20.8 \%$, tindakan sebesar $14.4 \%$ dan respon sebesar $15.8 \%$. berdasarkan hasil penilaian tersebut maka pelaksanaan pendampingan ini menagalami satu siklus. Dapat disimpulkan bahwa pendampingan sekolah siaga bencana pada Sekolah Budi Agung Jakarta sangat efektif dalam menanggulangi peristiwa kebencanaan atau kesiapsiagaan bencana yang akan terjadi.
\end{abstract}

Kata Kunci: Sekolah Siaga Bencana, Masyarakat

\section{Pendahuluan}

Berdasarkan Letak Geologis dan Geografis Indonesia mempunyai sumber daya alam hayati dan non hayati yang cukup melimpah, akan tetapi berdasarkan letak tersebut, Indonesia cukup rentan terhadap resiko bencana yang diakibatkan oleh alam dan manusia (Setyaningrum \& Sukma, 2020). Kerentanan terhadap resiko bencana alam dan sosial sangat diperlukan bagi setiap institusi. Program kesiagaan bencana pada setiap institusi khususnya institusi pendidikan yaitu sekolah sangat diperlukan. Secara harfiah bencana merupakan suatu peristiwa yang dapat mengintimidasi dan mengganggu kehidupan masyarakat secara umum, hal ini disebabkan oleh faktor alam dan sosial yang berdampak 
timbulnya korban jiwa dari masyarakat baik kerugian akan materil dan immateril, degradasi lingkungan serta dampak psikologis (Widjanarko \& Minnafiah, 2018). Berdasarkan tingkatan kematian yang disebabkan oleh bencana alam negara Indonesia berada di peringkat kedua di kawasan Asia Pasifik (Sasikome et al., 2015). Berdasarkan landasan yuridis penanggulangan bencana tertuang pada Undang-undang Nomor 24 tahun 2007 menjelaskan bahwa berdasarkan kondisi geografis, biologis, hidrologi dan demografi Wilayah Negara Kesatuan Republik Indonesia memungkinkan akan terjadinya berbagai jenis bencana, hal ini disebabkan oleh faktor-faktor alami, faktor non-alam dan faktor manusia yang menyebabkan korban manusia, kerusakan lingkungan, kerugian properti, dan psikologis berdampak pada pembangunan nasional dapat menghambat dalam keadaan wilayah tertentu (Buchari, 2020). Pada dasarnya terdapat prinsip-prinsip manajemen bencana yang meliputi sistem komando pada saat terjadi insiden bencana, manajemen darurat yang komprehensif, operasional mitIgasi bencana yang terintegrasi dan redundansi (Ha, 2020).

Pada Negara Indonesia banyak jumlah korban dari bencana merupakan peserta didik yang merupakan generasi penerus suatu bangsa yang harus dijaga keselamatannya. Faktor keterbatasan akan pemahaman dan pengetahuan dari resiko-resiko bencana yang akan terjadi pada lingkungan sekeliling pada perserta didik merupakan kerentanan yang harus dihadapi sehingga dalam hal ini diperlukan kesiapsiagaan dalam menghadapi bencana (Indriasari, 2018; Haryuni, 2018). Urgensi akan pengetahuan, sikap dan tindakan dari dan pengurangan risiko pada peristiwa suatu bencana harus diberikan pada anakanak di usia dini khususnya kelompok bermain dan taman kanak-kanak (Rahesli Humsona et al., 2019). Banyaknya jumlah korban bencana di Indonesia disebabkan karena minimya pengetahuan mitigasi bencana pada masyarakat Indonesia khususnya pelaku dalam dunia pendidikan (Hayudityas, 2020; Rahesli Humsona et al., 2019).

Provinsi DKI Jakarta merupakan Ibukota Indonesia yang mempunyai catatan peristiwa bencana alam dengan insentisitas yang cukup tinggi diantara provinsi-provinsi lain di Indonesia, seperti peristiwa banjir, kebakaran, kerusuhan, gempa bumi dan pandemi suatu penyakit. Berdasarkan data dari BNPB (Badan Nasional Penanggulangan Bencana) tahun 2017, bahwa provinsi-provinsi pada Pulau Jawa mempunyai tingkat kebencanaan yang tinggi seperti Provinsi Jawa Tengah, Jawa Barat dan DKI Jakarta, sedangkan untuk di Pulau Sumatra tingkat kebencanaan tertinggi terdapat pada Provinsi Aceh dan Sumatra Utara. Hal tersebut dapat dideskripsikan pada grafik data bencana berikut ini. 


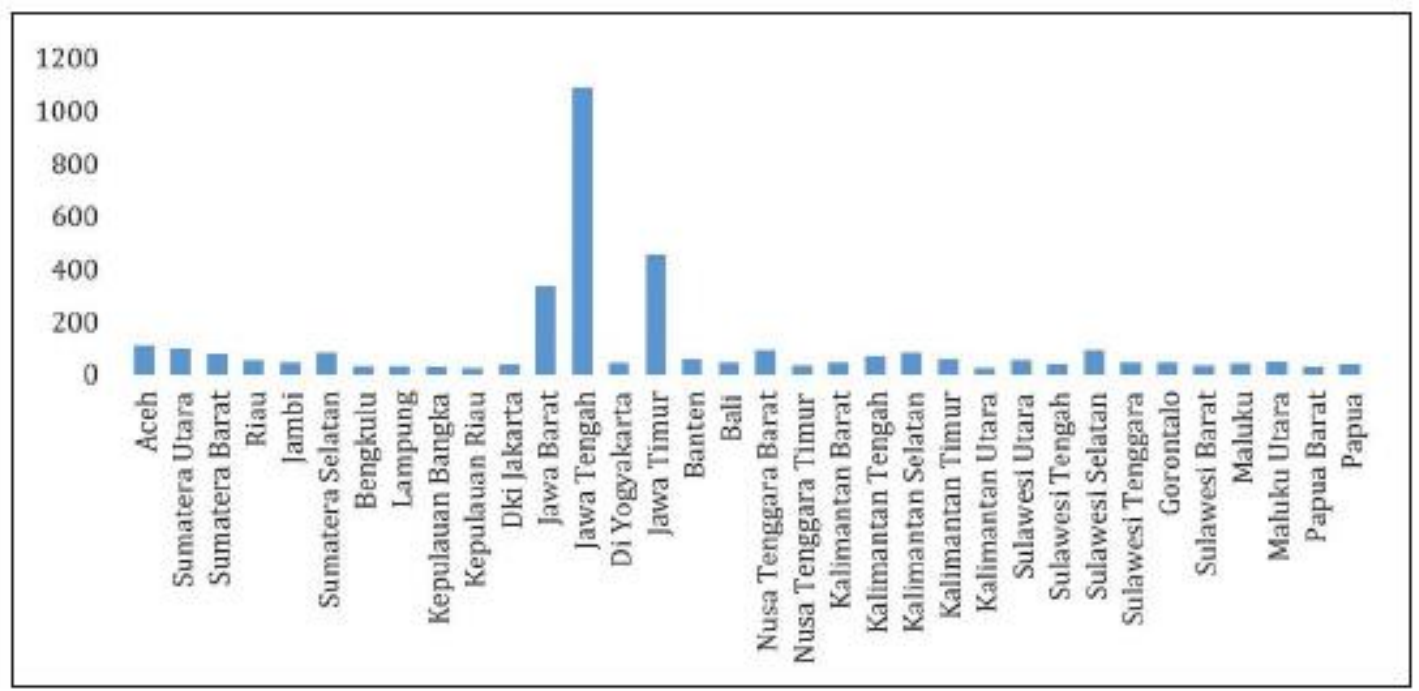

Sumber : Data Bencana Tahun 2017 BNPB

Gambar 1. Grafik Data Bencana Di Indonesia Pada Tahun 2017

Menurut Ayrizal dari Fadli Suhada, Persiapan atau kesiapan adalah suatu kondisi dan situasi yang dapat merespon dengan cepat dan akurat dari respons yang harus dihadapi secara kognitif, emosional dan mental (Suhada et al., 2014). Sedangkan kesiagaan adalah tindakan atau aktivitas yang dilakukan sebelum bencana (Widjanarko \& Minnafiah, 2018). Secara fundamental kesiapsiagaan bencana merupakan kebutuhan dasar bagi setiap orang untuk mengurangi risiko bencana yang terjadi kapanpun dan di tempat apapun (Hidayat, 2020). Keamanan sekolah yang komprehensif harus ditangani dengan menetapkan kebijakan pendidikan dalam hubungannya dengan kesiapsiagaan bencana dan mempraktikkannya di sekolah-sekolah di tingkat nasional, regional, kabupaten, kotamdya dan lokal. Tujuan keseluruhan dinyatakan dalam tiga pilar: (1) fasilitas belajar yang aman, (2) sekolah kesiapsiagaan bencana, dan (3) pelatihan pengurangan risiko bencana dan ketahanan (Kawasaki et al., 2020).

Pada faktanya yang bersumber data-data bencana di beberapa daerah, banyak korban jiwa terjadi pada kalangan anak usia sekolah, baik di sekolah di sekolah, hal ini menunjukkan bahwa pentingnya pengetahuan bencana dan pengurangan risiko bencana telah diberikan awal atau sejak dini (Rahesli Humsona et al., 2019). Program SSB (Sekolah Siaga Bencana) ini bertujuan untuk membentuk budaya waspada dan keselamatan di sekolah dan meningkatkan ketahanan mereka terhadap bencana oleh warga sekolah (Qoriandani \& Pambudi, 2020). Untuk membentuk Program Sekolah Siaga Bencana (SSB), ada empat hal yang harus dipenuhi diantarnya adalah 1) sikap dan tindakan dari seluruh warga sekolah 2) kebijakan dan aturan sekolah 3) rencana kesiapsiagaan bencana pada sekolah 4) sumber daya kebencanaan pada sekolah (Dewi, 2019). Bangunan sekolah yang kurang layak, rusaknya sarana prasarana sekolah dan rendahnya dan infrastruktur sekolah yang minim akan menimbulkan ancaman bencana dari keselamatan peserta didik, tenaga penddik dan tenaga kependidikan (Anisah \& Sumarni, 2019). Impelementasi sekolah siaga bencana terdiri tiga aspek utama yang harus ada didalam sekolah tersebut diantaranya adalah fasilitas sekolah yang aman, 
sekolah penanggulangan bencana dan pendidikan pengurangan dan pencegahan risiko bencana (Anisah \& Sumarni, 2019). Sekolah Siaga Bencana (SSB) merupakan sistem pencegahan bencana di sekolah-sekolah melalui peningkatan kesadaran semua elemen sekolah, baik budaya sekolah, infrastruktur sekolah dan penduduk sekolah baik secara individu dan kolektif pada waktu dan setelah bencana terjadi (Utama et al., 2018).

Pendidikan mitigasi bencana pada dekade ini, telah menjadi isu yang semakin banyak diteliti. Hal ini juga terkait dengan jumlah bencana yang menyebabkan kematian anak-anak usia sekolah. Sekolah pencegahan bencana yang didirikan di lingkungan sekolah memiliki pengetahuan tentang pengurangan risiko bencana untuk mencapai pencegahan bencana dan keselamatan dan menyebabkan hilangnya anak-anak usia sekolah (Qoriandani \& Pambudi, 2020; Wihyanti, 2018). Program SPAB (Satuan Pendidikan Aman Bencana) merupakan program yang telah dituang pada Permen Kemdikbud No. 33 Tahun 2019. Program ini berfungsi untuk bahwa untuk memberikan pelindungan dari peserta didik, tenaga pendidik dan tenaga kependidikan dari risiko bencana baik itu dari segi fisik dan psikologis serta menjamin keberlangsungan layanan pendidikan pada satuan pendidikan yang berdampak bencana sehingga dalam hal ini program kesiapsiagaan bencana pada Program SPAB mingkin bisa dimasukkan pada kurikulum sekoah yang berfungsi untuk mengurangi resiko bencana pada sekolah (Kasman, 2019).

Sekolah Pencegahan Bencana merupakan program berbasis masyarakat yang bertujuan untuk membangun kesiapsiagaan masyarakat terhadap potensi bencana di Indonesia (Angraini et al., 2019). Belajar dari sejarah dan pengalaman dari berbagai peristiwa bencana baik itu yang diakibatkan oleh alam dan manusia di Indonesia, maka urgensi pendidikan dan pelatihan kesiapsiagaan dari bencana dimulai pada tingkat pendidikan usia dini, dasar dan menengah dalam membangun dan membentuk budaya keselamatan dan ketahanan resiko bencana, khususnya bagi anak-anak usia dini dan generasi muda (Daud et al., 2014). Urgensi kesiapsiagaan darurat juga merupakan tanggung jawab sekolah sebagai lembaga pendidikan yang lahir dari masyarakat. Pendidikan kesiapsiagaan bencana dimulai dari usia yang sangat muda (Al-Nashr, 2018). Tindakan persiapan mengacu pada tindakan yang diambil untuk merencanakan dan mengurangi dampak bencana. Dengan kata lain, prediksi bencana, mitigasi dan respon yang efektif dan manajemen bencana pada populasi rentan adalah mungkin (Shah et al., 2020). Ketahanan sekolah sangat ditentukan oleh kontribusi guru dan siswa serta masyarakat. Oleh karena itu, kontribusi guru dan siswa menjadi penting dalam membangun ketahanan sekolah, terutama di sekolah-sekolah yang berada di daerah rawan bencana (Dwiningrum, 2017).

\section{Metode}

Pada Program Pendampingan Sekolah Siaga Bencana Berbasiskan Masyarakat pada Sekolah Budi Agung yang dilakukan pada jenjang Taman Kanak-Kanak, Sekolah Dasar, Sekolah Menengah Pertama, Sekolah Menengah Kejuruan dan Sekolah Menengah Atas melalui Metode PAR (Participatory Action Research) dengan tahapan siklus 
identifikasi masalah, perencanaan tindakan dalam bentuk perencanaan pendampingan, Pelaksanaan tindakan, Refleksi tindakan dalam bentuk evaluasi pendampingan.

Program ini mengoptimalkan peran masyarakat pada sekitar lingkungan sekolah dalam membantu pengurangan risiko bencana dan tanggap bencana dalam membantu perserta didik Sekolah Budi Agung Jakarta dengan jumlah perserta berjumlah 85 orang yang tediri dari 68 orang tenaga pendidik, 7 tenaga kependidikan dan 10 masyarakat disekitar sekolah. Program ini terdiri dari beberapa tahapan diantaranya adalah 1) Sosialisasi terhadap guru, siswa dan masyarakat disekitar sekolah tentang mitigasi bencana 2) Pembuatan jalur evakuasi 3) Pelatihan tanggap bencana yang dilakukan oleh guru, siswa dan masyarakat sekitar sekolah 4) Pembentukan tim tanggap bencana sekolah 5) Evaluasi program melalui tes tertulis dan praktikum kesiagapan terhadap bencana yang akan terjadi di sekolah.

\section{Hasil Dan Pembahasan}

\section{Sosialisasi Mitigasi Bencana}

Kegiatan sosialisasi mitigasi bencana yang dilakukan di Sekolah Budi Agung Jakarta dihadiri oleh tenaga pendidik, tenaga kependidikan, masyarakat disekitar sekolah dan peserta didik, mengingat hal ini penting sehingga banyak para perserta sosialisasi juga tertarik untuk memperhatikan. Dengan acara ini seluruh perserta merasa sangat senang karena mereka mendapatkan pengalaman dan pengetahuan baru terutama dalam hal mitigasi bencana. Selain itu, tenaga pendidik dan kepala sekolah juga merasa sangat bahagia karena mereka mendapatkan pengalaman dan pengetahuan baru. Melalui implementasi sosialisasi ini, sekolah memiliki inisiasi untuk menjadikan Sekolah Budi Agung Jakarta sebagai salah satu sekolah yang aman akan bencana. Mengingat ini sangat penting karena posisi area Kotamadya Jakarta Utara sangat rentan dengan bencana, terutama gempa bumi, tsunami, kebakaran dan pandemi. Selain itu, tenaga pendidik, tenaga kependidikan dan masyarakat sekitar sekolah dapat lebih memahami tanggung jawab mereka jika sewaktu-waktu bencana di sekolah. Mengingat bahwa tanggung jawab mereka sangat besar jika ada bencana di sekolah, oleh karena itu hal ini terasa sangat penting dan bermanfaat bagi tenaga pendidik, tenaga kependidikan dan masyarakat sekitar sekolah.

Pemberian informasi pada sub program sosialisasi dilakukan oleh BPBD Kotamadya Jakarta Utara dengan memberikan informasi dari materi-materi: 1) Jenis-jenis bencana 2) Mitigasi bencana 3) Evakuasi dari setiap jenis-jenis bencana. Sosialisasi tersebut merupakan bentuk penyampaian informasi pada setiap peserta pendampingan. Pada proses sosialisasi disini, akan membentuk kesadaran bagi perserta perserta dalam membentuk kesadaran dan tindakan yang akan dilakukan dalam menghadapi bencana.

Pada pelaksanaan sosialisasi bencana dari para peserta pendampingan mempunyai antusias yang sangat tinggi, hal ini disebabkan oleh beberapa faktor yaitu: 1) minimnya wawasan dan pengetahuan kebencanaan dari para peserta 2) Sosialisai mitigasi bencana merupakan hal yang baru bagi para peserta pendampingan 3) Sosialisasi mitigasi bencana merupakan suatu hal yang sangat penting bagi para peserta pada saat menghadapi 
Jurnal Pengabdian Masyarakat As-Salam (JPMA)

Vol. 1 No. 1 Januari - Juni 2021: 24 - 34

Farid Fauzi, Sri Rahayu Handayani

bencana. Selain itu peran sosialisasi mitigasi bencana bagi para peserta dapat memberikan manfaat yang berupa 1) Pemahaman akan mitigasi bencana 2) Mengenal langkah-langkah dalam mitigasi bencana 3) Memberikan pengetahuan kepada perserta tentang jenis-jenis bencana.

\section{Pembuatan Jalur Evakuasi Bencana Pada Kawasan Sekolah}

Pada manajemen kebencanaan proses kesiapsiagaan, pencegahan dan perlindungan dari kebencanaan merupakan suatu hal yang sangat penting dalam meminimalisir kerentanan yang diakibatkan oleh bencana. Jalur evakuasi merupakan suatu faktor yang penting dari beberapa faktor dari mitigasi bencana. Belum terbentuk dan minimnya jalur evakasi bencana pada tempat publik, pusat pelaanan, perekonomian, tempat ibadah dan industri merupakan hal yang dapat memungkinkan besarnya jumlah korban bencana. Berdasrkan fakta yang ada pada sekolah Budi Agung belum terdapatnya jalur evakuasi yang menjadi bagian yang sangat penting dalam proses evakuasi. Pembuatan jalur dan lokasi evakuasi bencana pada Sekolah Budi Agung dibentuk berdasarkan struktur bangunan dan fasilitas yang mendukung dari proses evakuasi. Lokasi evakuasi pada Sekolah Budi Agung akan direncanakan pada lapangan olah raga yang berada disamping gedung sekolah sedangkan jalur evakuasi pada tangga darurat yang berada disisi kanan Gedung Sekolah Budi Agung.

Pada pelaksanaannya pembuatan jalur evakuasi yang dilakukan para peserta Pendampingan Program Sekolah Siaga Bencana Berbasiskan Masyarakat Pada Sekolah Budi Agung sangartlah baik, hal ini dibuktikan dengan pembautan jalur evakuasi yang berada disamping kelas sampai dengan lokasi evakuasi yang berada di Lapangan Sekolah Budi Agung dengan membantuk tanda arah atau petunjuk jalan dalam proses penyelamatan diri pada saat terjadinya bencana serta tempat ata zona berkumpulnya para perserta didik, tenaga pendidik dan kependidikan pada saat terjadinya bencana. Jalur evakuasi yang dibuat merupakan jalur yang mudah dan dapat diakses oleh setiap peserta didik dari tingkatan Pendidikan Anak Usia Dini, Sekolah Dasar, Sekolah Menengah Pertama, Sekolah Menengah Atas dan Sekolah Menengah Kejuruan

\section{Pelatihan Tanggap Bencana}

Kegiatan simulasi atau pelatihan evakuasi dilakukan pada hari keempat. Setelah semua tenaga pendidik, tenaga kependidikan dan masyarakat sekitar sekolah memahami peran partisipasi masing-masing, tahap selanjutnya adalah simulasi kegiatan mitigasi bencana, dalam hal ini bencana gempa bumi, kebakaran, banjir, kerusuhan dan tsunami. Pelatihan kepada tenaga pendidik, tenaga kependidikan dan masyarakat sekitar sekolah. sangat diperlukan, sehingga tenaga pendidik, tenaga kependidikan dan masyarakat sekitar sekolah memahami apa yang harus dilakukan ketika bencana terjadi. Pelatihan yang dilakukan tidak hanya melibatkan tenaga pendidik, tenaga kependidikan dan masyarakat sekitar sekolah, tetapi juga terkait dengan sukarelawan dan BPBD Jakarta Utara. Pelatihan ini evakuasi atau simulasi bencana dilakukan untuk mempersiapkan lebih lanjut tenaga pendidik, tenaga kependidikan dan masyarakat sekitar sekolah dengan kondisi nyata jika terjadi kebakaran, banjir, gempa bumi dan tsunami yang nyata. Apa yang akan dilakukan, item apa yang akan dibawa dan ke arah yang harus menyelamatkan diri 
mereka dan siapa yang diselamatkan terlebih dahulu dan sebagainya. Simulasi bencana dibuat lebih untuk menyiapkan kondisi tenaga pendidik, tenaga kependidikan dan masyarakat sekitar sekolah dalam menghadapi bencana dan mengurangi situasi kepanikan sebagai akibat dari berpartisipasi dalam bencana yang dapat menambah jatuhnya korban.

Latihan evakuasi atau simulasi bencana dibuat untuk mempersiapkan peserta didik, tenaga pendidik dan tenaga kependidikan untuk kondisi nyata jika terjadi bencana baik itu alam dan manusia. Dalam pelatihan ini para perserta diajarkan tentang apa yang harus dilakuakan pada saat terjadinya bencana, apa yang harus diselematkan terlibih dahulu, barang-barang apa saja yang harus diselamatkan terlebih dahulu pada saat bencana, cara mengurangi kepanikan pada saat terjadinya bencana serta cara meminimalisir bencana dengan sarana prasarana dan peralatan yang ada di Sekolah Budi Agung seperti tabung pemadam kebakaran, karung dan tambang.

\section{Pembentukan Tim Tanggap Bencana Sekolah}

Memang, pendidikan peringatan bencana diajarkan bersama dengan materi pelajaran yang ada, yaitu menghubungkan setiap material dengan peringatan bencana yang akan menumbuhkan sikap dan perilaku siaga bencana untuk anak-anak. Materi yang disajikan harus sederhana, konkret dan dekat dengan dunia anak-anak. Mengintegrasikan pendidikan peringatan bencana ke dalam pembelajaran sekolah akan dapat menanamkan kognisi peringatan bencana dan menghasilkan perilaku respons bencana. Menciptakan budaya peringatan bencana membutuhkan dukungan dari semua elemen sekolah, terutama budaya yang berlaku di sekolah. Integrasi pendidikan peringatan bencana dalam setiap kegiatan sekolah dan peraturan akan semakin mempertajam aspek-aspek pengetahuan dan keterampilan siaga bencana untuk elemen sekolah. Jika sudah menjadi budaya, pencegahan dapat diwujudkan maksimal.

Realisasi tim tanggap bencana pada Sekolah Budi Agung terdiri dari beberapa orang yang mempunyai kompetensi dan otoiritas dalam penanganan bahaya seperti pertugas, keamanan, pramubakti, tenaga pendidik dan staf sekolah. Pembentukan tim tanggap bencana di Sekolah Budi Agung dapat berdasarkan pengetahuan seseorang dari bahaya bencana, pengalaman dalam menanggulangi bencana, kepemimpinan, kooperatif dan mempunyai kapasitas dalam menggunakan peralatan dalam mengurangi bencana yang terjadi.

\section{Evaluasi Program Sekolah Siaga Bencana}

Secara umum, setiap komunitas sekolah memberikan nilai dan apresiasi yang baik dalam menanggapi. Rata-rata jawaban terasa senang ikut serta dalam pelatihan dan simulasi yang dilakukan untuk kesiapsiagaan bencana gempa. Beberapa merasa pelatihan diikuti adalah hal baru. Dengan mengikuti pelatihan ini, mereka lebih memahami kesiapsiagaan bencana, terutama gempa bumi dan minat untuk mengikuti pelatihan berikutnya untuk meningkatkan wawasan kesiapsiagaan bencana.

Berdasarkan data hasil evaluasi antara sebelum dan sesudah pendampingan terdapat peningkatan nilai dari pengetahuan, sikap, tindakan dan respon terhadap kesiapsiagaan bencana dari para peserta pendampingan sekolah siaga bencana yang dapat dilihat pada grafik dibawah ini. 
Jurnal Pengabdian Masyarakat As-Salam (JPMA)

Vol. 1 No. 1 Januari - Juni 2021: 24 - 34

Farid Fauzi, Sri Rahayu Handayani

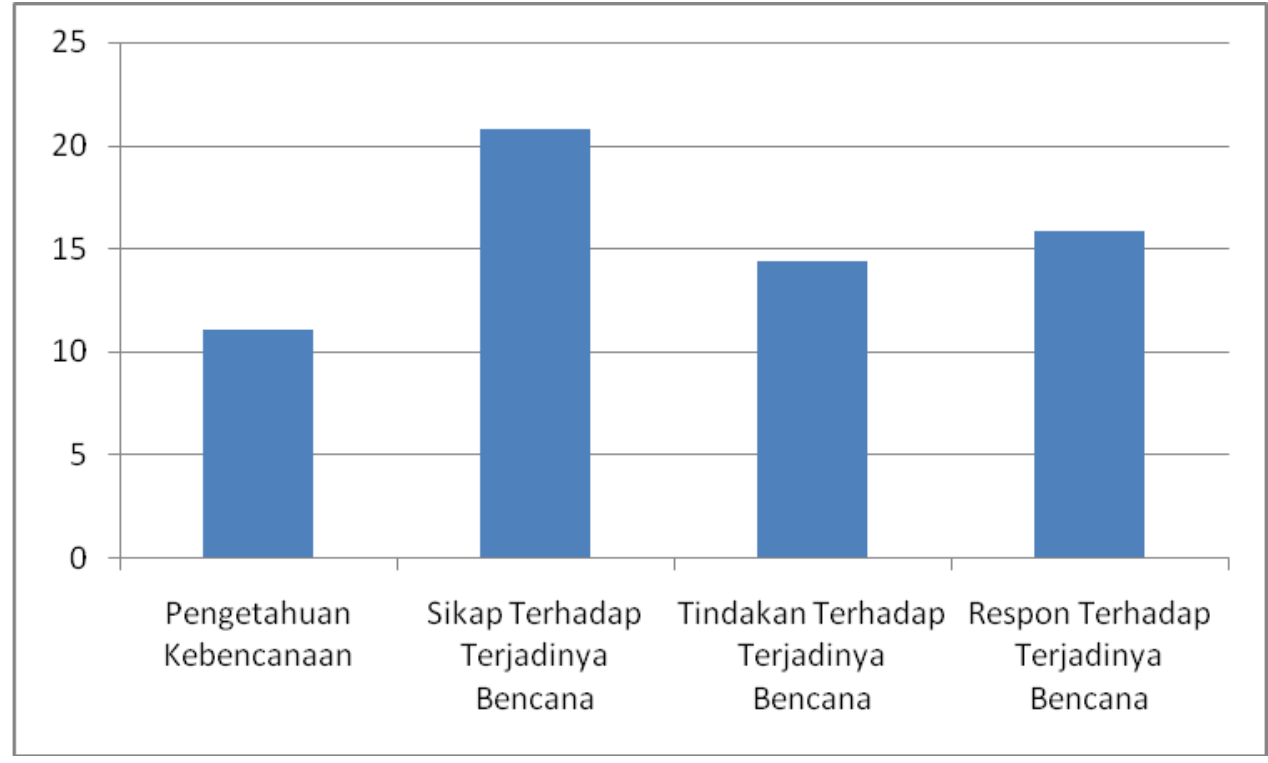

Sumber : Hasil Evaluasi Dari Para Peserta Pendampingan Sekolah Siaga Bencana

Gambar 2. Grafik Prosentase Evaluasi Kesiapsiagaan Bencana

Berdasarkan hasil evaluasi tersebut dapat diinterpretasikan bahwa dalam mewujudkan budaya peringatan bencana, diperlukan pengetahuan, sikap, tindakan dan respon yang akan dilakukan pada saat terjadinya bencana, tidak itu saja semua elemen yang ada disekolah baik sumber daya manusia, fasilitas gedung dan sarana prasarana yang dapat meminimalisir terjadinya bencana sangat dibutuhkan. Selain itu, integrasi pendidikan dan program kesiapsiagaan bencana pada Sekolah Budi Agung Jakarta harus diimplementasikan pada produk kurikulum yang terdapat sekolah tersebut, sehingga aplikasi budaya pencegahan di Sekolah Budi Agung dapat diwujudkan secara optimal.

Pada pelaksanaan pengabdian masyarakat dari Pendampingan Program Sekolah Siaga Bencana Pada Sekolah Budi Agung melalui Metode PAR (Participatory Action Research) dilaksanakan dengan satu siklus, hal ini berdasarkan hasil dari evaluasi pendampingan program sekolah siaga bencana yang diikuti oleh tenaga pendidik, tenaga kependidikan dan masyarakat sekitar sekolah yang mengalami peningkatan yang cukup signifikan dari beberapa unsur-unsur penilaian seperti pengetahuan kebencanaan sebesar $11 \%$, sikap terjadinya bencana sebesar $20.8 \%$, tindakan terhadap terjadinya bencana sebesar $14.4 \%$ dan respon terhadap terjadinya bencana sebesar $15.8 \%$. Peningkatan kapasitas dan kapabilitas dari kesiapsiagaan bencana memberikan dampak yang baik terhadap seluruh perserta dalam menghadapi peristiwa bencana yang akan terjadi.

\section{Kesimpulan}

Berdasarkan hasil kegiatan maka dapat ditarik beberapa kesimpulan diantaranya adalah

1. Bahwa pembentukan sekolah siaga bencana berbasiskan masyarakat merupakan suatu program pemberdayaan masyarakat disekitar Sekolah Budi Agung Jakarta dalam membentuk kesiapsiagaan dalam kebencanaan, hal ini dapat diartikan bahwa kesiapsiaagan bencana pada Sekolah Budi Agung Jakarta tidak dapat berdiri sendiri 
akan tetapi perlu adanya peran dan partisipasi masyarakat disekitar sekolah.

2. Pada program pendampingan sekolah siaga bencana pada Sekolah Budi Agung berbasiskan masyarakat telah membentuk dan menambah pengetahuan dalam mitigasi bencana dan keterampilan dari tindakan yang harus dilakukan dalam menghadapi bencana pada masyarakat sekolah dan sekitar sekolah.

3. Pelatihan dari simulasi kesiapsiagaan bencana pada program pendampingan sekolah siaga bencana di Sekolah Budi Agung Jakarta akan dapat menguruangi resiko bencana baik itu yang diebabkan oleh alam dan manusia.

4. Melalui pendampingan ini masyarakat sekolah dan disekitar sekolah dapat menghadapi keadaan darurat bencana di lingkungan sekolah. Kesiapsiagaan bencana gempa bumi, kebakaran, banjir, tsunami, kerusushan dan pandemi di sekolah dapat dikelola dengan baik melalui keterlibatan aktif antara sekolah dan pihak yang berkepentingan dalam keadaan darurat bencana.

\section{Ucapan Terima Kasih}

Terima kasih setingi-tingginya disampaikan untuk segenap pihak yang terlibat dalam aktivitas pengabdian masyarakat ini. Kepada pengelola jurnal pengabdian masyarakat As-Salam (JPMA) kami sampaikan penghargaan yang dalam telah mempublikasikan laporan kegiatan ini.

\section{Daftar Pustaka}

Al-Nashr, M. S. (2018). Integrasi Pendidikan Siaga Bencana Dalam Kurikulum Madrasah Ibtidaiyah. MAGISTRA: Media Pengembangan Ilmu Pendidikan Dasar Dan Keislaman, 6(2). 82-101. Https://Doi.Org/10.31942/Mgs.V6i2.1779

Angraini, L. M., Syamsuddin, S., Wirawan, R., Qomariyah, N., \& Sukrisna, B. (2019). Pendampingan Sekolah Siaga Bencana Sebagai Upaya Mitigasi Bencana Di SMK Kehutanan Qomarul Huda Lombok Barat. Jurnal Pengabdian Magister Pendidikan IPA, 1(2). 58-64.

Https://Doi.Org/10.29303/Jpmpi.V1i2.263

Anisah, N., \& Sumarni, S. (2019). Model Sekolah Aman Bencana Dalam Upaya Mewujudkan Pendidikan Karakter Di MIN 1 Bantul. LITERASI (Jurnal Ilmu Pendidikan), 10(1). 9-20.

Https://Doi.Org/10.21927/Literasi.2019.10(1).9-20

Buchari, A. (2020). Bencana Dengan Kelembagaan Masyarakat Di Daerah Rawan Bencana Kabupaten Garut Indonesia. Sawala: Jurnal Pengabdian Masyarakat Pembangunan Sosial, Desa Dan Masyarakat, 1(1), 1-10. Https://Doi.Org/10.24198/Sawala.V1i1.25836

Daud, R., Sari, S. A., Milfayetty, S., \& Dirhamsyah, M. (2014). Penerapan Pelatihan Siaga Bencana Dalam Siaga Meningkatan Pengtetahuan, Sikap, Dan Tindakan Komunitas SMA Negeri 5 Banda Aceh. Jurnal Ilmu Kebencanaan (JIKA), 1(1). 2634.

Http://Www.Jurnal.Unsyiah.Ac.Id/JIKA/Article/View/2470 
Jurnal Pengabdian Masyarakat As-Salam (JPMA)

Vol. 1 No. 1 Januari - Juni 2021: 24 - 34

Farid Fauzi, Sri Rahayu Handayani

Dewi, A. R. (2019). Gambaran Penerapan Kebijakan Sekolah Siaga Bencana Tingkat Sekolah Dasar Di Yogyakarta [Jurusan Ilmu Kesehatan Masyarakat]. Universitas Negeri Semarang.

Dwiningrum, S. I. A. (2017). Developing School Resilience For Disaster Mitigation: A Confirmatory Factor Analysis. Disaster Prevention And Management: An International Journal, 26(4). 437-451.

Https://Doi.Org/10.1108/DPM-02-2017-0042

Ha, K.-M. (2020). Disaster Management: From A One-Sided Approach To An Inclusive System. Environment Systems And Decisions, 40(3). 403-412. Https://Doi.Org/10.1007/S10669-019-09755-X

Haryuni, S. (2018). Pengaruh Pelatihan Siaga Bencana Gempa Bumi Terhadap Kesiapsiagaan Anak Usia Sekolah Dasar Dalam Menghadapi Bencana Gempa Bumi Di "Yayasan Hidayatul Mubtadiin Kediri. Jurnal Ilmu Kesehatan, 6(2). 133139.

Https://Doi.Org/10.32831/Jik.V6i2.167

Hayudityas, B. (2020). Pentingnya Penerapan Pendidikan Mitigasi Bencana Di Sekolah Untuk Mengetahui Kesiapsiagaan Peserta Didik. Jurnal Edukasi Nonformal, 1(2). 94-102.

Retrieved From Https://Ummaspul.E-Journal.Id/JENFOL/Article/View/407.

Hidayat, L. (2020). Pengembangan Buku Kesiapsiagaan Bencana Untuk Sekolah Inklusi (Hasil Analisis Sekolah Ramah Anak Di Sleman Yogyakarta). Elementary School, 7(1). 58-68.

Https://Doi.Org/10.31316/Esjurnal.V7i1.480

Indriasari, F. N. (2018). Pengaruh Pemberian Metode Simulasi Siaga Bencana Gempa Bumi Terhadap Kesiapsiagaan Anak Di Yogyakarta. Jurnal Keperawatan Soedirman, 11(3). 1-7.

Https://Doi.Org/10.20884/1.Jks.2016.11.3.700

Kasman, R. (2019). Biimbingan Satuan Pendidikan Aman Bencana Bagi Guru Dan Tenaga Kependidikan Pasca Bencana Di Kota Palu, Sigii Dan Donggala. Jurnal Obor Penmas, 2(1). 67-77.

Http://Dx.Doi.Org/10.32832/Oborpenmas.V2i1.2251

Kawasaki, H., Yamasaki, S., Rahman, M. M., Murata, Y., Iwasaa, M., \& Teramoto, C. (2020). Teachers-Parents Cooperation In Disaster Preparation When Schools Become As Evacuation Centers. International Journal Of Disaster Risk Reduction, 44, 101445.

Https://Doi.Org/10.1016/J.Ijdrr.2019.101445

Qoriandani, M., \& Pambudi, D. I. (2020). Implementasi Sekolah Siaga Bencana Pada SD Unggulan Aisyiyah Bantul. Elementary School: Jurnal Pendidikan Dan Pembelajaran Ke-SD-An, 7(2). 247-253.

Https://Doi.Org/10.31316/Esjurnal.V7i2.753

Https://Doi.Org/10.31316/Esjurnal.V7i2.753

Rahesli Humsona, Sri Yuliani, \& Sigit Pranawa. (2019). Kesiapsiagaan Anak Dalam Menghadapi Bencana: Studi Di Kabupaten Sleman. Talenta Conference Series: Local Wisdom, Social, And Arts (LWSA), 2(1). 1-8.

Https://Doi.Org/10.32734/Lwsa.V2i1.619

Sasikome, J. R., Kumaat, L. T., \& Mulyadi. (2015). Pengaruh Penyuluhan Bencana Banjir Terhadap Kesiapsiagaan Siswa SMP Katolik Soegiyo Pranoto Manado Menghadapi Banjir. Ejournal Keperawatan (E-Kp), 3(2). 1-8. Https://Ejournal.Unsrat.Ac.Id/Index.Php/Jkp/Article/View/8030 
Setyaningrum, Y. I., \& Sukma, G. I. (2020). Pelatihan Pengurangan Risiko Bencana (Prb) Stikes WCH Bekerja Sama Dengan SMA/SMK Malang. Indonesian Journal of Community Services, 2(1). 92-100.

Http://Dx.Doi.Org/10.30659/Ijocs.2.1.92-100

Https://Doi.Org/DOI: Http://Dx.Doi.Org/10.30659/Ijocs.2.1.92-100

Shah, A. A., Gong, Z., Pal, I., Sun, R., Ullah, W., \& Wani, G. F. (2020). Disaster Risk Management Insight On School Emergency Preparedness - A Case Study Of Khyber Pakhtunkhwa, Pakistan. International Journal Of Disaster Risk Reduction, 51, 101805. Https://Doi.Org/10.1016/J.Ijdrr.2020.101805

Suhada, F., Khairuddin, \& Dirhamsyah. (2014). Dentifikasi Kesiapsiagaan Komunitas Sekolah SMA Negerii 2 Kluet Utara Dalam Menghadapi Bencana Gempa Bumi Dan Tsunami. Jurnal Ilmu Kebencanaan (JIKA), 1(2).9-15.

Http://Jurnal.Unsyiah.Ac.Id/JIKA/Article/View/5592

Utama, R. I., Syah, N., Rifwan, F., Sari, N. M., \& Yandra, M. (2018). Penerapan Dan Sosialisasi Sekolah Siaga Bencana Bagi Anak-Anak Sekolah Dasar Di Kabupaten Agam. CIVED, 5(4). 0-0. Https://Doi.Org/10.24036/Cived.V5i4.102629

Widjanarko, M., \& Minnafiah, U. (2018). Pengaruh Pendidikan Bencana Pada Perilaku Kesiapsiagaan Siswa. Jurnal Ecopsy, 5(1). 1-7. Https://Doi.Org/10.20527/Ecopsy.V5i1.4878

Wihyanti, R. (2020). Analisis Inovasi Pendidikan Kebencanaan Di Sekolah Di Indonesia. Wijayakusuma Prosiding Seminar Nasional, 1(1). 16-21. https://ejournal.unugha.ac.id/index.php/jarlit/article/view/261 